\section{Improved Transfection Efficiency of 293 Cells by Radio Frequency Electroporation}

BioTechniques 28:418-420 (March 2000)

Electroporation, a widely used technique allowing the transfer of biological molecules into a variety of cell types (13), has been used with success for introducing plasmids and short oligonucleotides into mammalian, yeast and a variety of other cell types $(1,2,9,10)$. A modification of the square-wave pulse technique that uses radio frequency $(\mathrm{RF})$ electrical bursts is now being used effectively for transient transfections (5). RF electroporation uses bursts of sinusoidal waves, similar to alternating current $(3,4)$ that reportedly result in better transient permeation of the cell membrane (6). This type of electroporation uses protocols and equipment already familiar to users of previously available types of electroporation. Consequently, the RF procedure can be useful to incorporate in a variety of investigations for creation of stable cell lines and in transient transfections. We describe here optimized RF electroporation parameters for the 293 human embryonic kidney cell line.

Plasmid EGFP (Clontech Laboratories, Palo Alto, CA, USA) was prepared from stock solution $(4.9 \mu \mathrm{g} / \mu \mathrm{L})$ in quantities of $10 \mu \mathrm{g}$ by cold ethanol/ sodium acetate precipitation and resuspended in $400 \mu \mathrm{L}$ aliquots of phosphate-buffered sucrose electroporation medium: $150 \mathrm{mM}$ sucrose, $27 \mathrm{mM}$ $\mathrm{Na}_{2} \mathrm{HPO}_{4}$, pH 7.5 (3). The 293 cells obtained from Elliott Kieff (Harvard Medical School) were maintained in DMEM (Life Technologies, Gaithersburg, MD, USA) supplemented with $10 \%$ fetal bovine serum, $2 \mathrm{mM}$ L-glutamine, $25 \mathrm{U} / \mathrm{mL}$ penicillin, $25 \mu \mathrm{g} / \mathrm{mL}$ streptomicin and $10 \mu \mathrm{g} / \mathrm{mL}$ gentamicin, allowed to reach $70 \%$ confluency, then harvested by trypsin/PBS and vigorous pipetting for $30 \mathrm{~s}$. Trypsinization was stopped by addition of complete media supplemented with fetal bovine serum, and cell counts were determined by trypan blue staining. Approximately $5 \times$ $10^{6}$ cells were washed with PBS, resus-

Table 1. Transfection Efficiency at Various Radio Frequency Electroporation Settings, Presented as the Average of Independent Transfections

\begin{tabular}{|c|c|c|c|}
\hline & Voltage & $\begin{array}{l}\text { RF Burst Duration (ms) } \\
\text { or Standard } \\
\text { Capacitance }(\mu \mathrm{F})\end{array}$ & $\begin{array}{c}\text { Transfection Efficiency } \\
\text { (Percent } \\
\text { Transfected Cells) }\end{array}$ \\
\hline $\mathrm{RF}$ & 200 & $3 \mathrm{~ms}$ & $40 \% \pm 2.0 \%$ \\
\hline RF & 200 & $4 \mathrm{~ms}$ & $39 \% \pm 2.5 \%$ \\
\hline $\mathrm{RF}$ & 200 & $5 \mathrm{~ms}$ & $33 \% \pm 5.5 \%$ \\
\hline STANDARD & 200 & $975 \mu \mathrm{F}$ & $18 \% \pm 3.5 \%$ \\
\hline RF & 210 & $3 \mathrm{~ms}$ & $40 \% \pm 2.5 \%$ \\
\hline $\mathrm{RF}$ & 210 & $4 \mathrm{~ms}$ & $48 \% \pm 6.0 \% a$ \\
\hline RF & 210 & $5 \mathrm{~ms}$ & $43 \% \pm 3.5 \%$ \\
\hline STANDARD & 210 & $975 \mu \mathrm{F}$ & $20 \% \pm 3.5 \%$ \\
\hline $\mathrm{RF}$ & 220 & $3 \mathrm{~ms}$ & $39 \% \pm 2.5 \%$ \\
\hline $\mathrm{RF}$ & 220 & $4 \mathrm{~ms}$ & $41 \% \pm 4.0 \% a$ \\
\hline $\mathrm{RF}$ & 220 & $5 \mathrm{~ms}$ & $40 \% \pm 7.5 \%$ \\
\hline STANDARD & 220 & $975 \mu \mathrm{F}$ & $30 \% \pm 2.5 \%$ \\
\hline $\mathrm{RF}$ & 230 & $3 \mathrm{~ms}$ & $48 \% \pm 2.0 \%$ \\
\hline $\mathrm{RF}$ & 230 & $4 \mathrm{~ms}$ & $56 \% \pm 16 \% a$ \\
\hline RF & 230 & $5 \mathrm{~ms}$ & $45 \% \pm 4.5 \%$ \\
\hline STANDARD & 230 & $975 \mu \mathrm{F}$ & $20 \% \pm 0.5 \%$ \\
\hline $\mathrm{RF}$ & 240 & $3 \mathrm{~ms}$ & $40 \% \pm 8.0 \%$ \\
\hline $\mathrm{RF}$ & 240 & $4 \mathrm{~ms}$ & $34 \% \pm 4.5 \%$ \\
\hline $\mathrm{RF}$ & 240 & $5 \mathrm{~ms}$ & $25 \% \pm 11 \%$ \\
\hline STANDARD & 240 & $975 \mu \mathrm{F}$ & $24 \% \pm 3.0 \%$ \\
\hline \multicolumn{4}{|c|}{$\begin{array}{l}\text { aElectroporation conditions where maximum transfection efficiencies were con- } \\
\text { sistently obtained. } \\
\text { Percent transfected cells is defined as the percentage of cells present exhibiting } \\
\text { GFP fluorescence } 24 \mathrm{~h} \text { after transfection. A manual count of three separate } 100 \text { - } \\
\text { cell fields was made for each independent trial. Standard electroporation was } \\
\text { performed at similar voltages as those for the RF transfections at a capacitance } \\
\text { of } 975 \mu \mathrm{F} \text { with delivery of one pulse. }\end{array}$} \\
\hline
\end{tabular}

pended in the previously prepared aliquots of electroporation medium containing EGFP plasmid. Pellets were then pipetted vigorously to ensure uniform suspension of single cells. This suspension was then immediately transferred to a $0.4 \mathrm{~cm}$ electroporation cuvette (Eppendorf Scientific, Westbury, NY, USA). Cells were pulsed at various voltages (200-240 V) and burst duration combinations (3-5 ms) using the Gene Pulser II ${ }^{\circledR}$ RF Module for the Gene Pulser II Electroporation System (BioRad Laboratories, Hercules, CA, USA). The remaining electroporation parameters were held constant for all experiments: $100 \%$ modulation, 40 $\mathrm{kHz}$ radio frequency, 5 bursts and $1 \mathrm{~s}$ interval between bursts. The cell sus- pension was immediately transferred to $10 \mathrm{~mL}$ of complete culture medium (as described above) and placed in a $37^{\circ} \mathrm{C}$, $5 \% \mathrm{CO}_{2}$ incubator overnight. After 24 $\mathrm{h}$, cells were again harvested by trypsin/PBS, washed in media and resuspended in $500 \mu \mathrm{L}$ PBS. Transfection efficiency was detected by fluorescence microscopy using Model IX70 microscope and 1X-FLA Fluorescence Observation ${ }^{\circledR}$ attachment (both from Olympus America, Melville, NY, USA). A 405, 490, $570 \mathrm{~nm}$ triple filter was used for optimum excitation of GFP. Percent transfection was measured as the average of three 100-cell fields counted manually under low power and is defined as the percent of cells exhibiting GFP fluorescence. 
Results are presented as the average of multiple independent transfection experiments (Table 1). Equivalent transfections were carried out at each voltage setting using both radio frequency and standard pulse electroporation. Cells transfected at voltages in the range of 210-240 V with burst durations ranging from $3-5 \mathrm{~ms}$ had relatively high transfection efficiencies. Specifically, we obtained an average of $40 \%, 48 \%$ and $43 \%$ transfected cells at $210 \mathrm{~V}$ and 3, 4 and $5 \mathrm{~ms}$ burst duration, respectively, with standard deviation within $2 \%-5.5 \%$. At $220 \mathrm{~V}$ and 3, 4 and $5 \mathrm{~ms}$ burst duration, respectively, we obtained an average of $39 \%, 41 \%$ and $40 \%$ transfected cells. Finally, at $230 \mathrm{~V}$ and 3, 4 and $5 \mathrm{~ms}$, we obtained an average of $48 \%, 56 \%$ and $45 \%$ transfected cells. The best results were obtained at $210 \mathrm{~V}$ and $4 \mathrm{~ms}(48 \%$ average), as well as at $230 \mathrm{~V}$ and $4 \mathrm{~ms}$ burst duration (56\% average). In the most effective range of settings $(210 \mathrm{~V}$ and 4 $\mathrm{ms}$, or $230 \mathrm{~V}$ and $4 \mathrm{~ms}$ ) approximately $15 \%-25 \%$ of cells were killed by the radio frequency electroporation as measured by cell counts and trypan blue staining $24 \mathrm{~h}$ after shock (data not shown). Cell viability following standard pulse electroporation was consistently lower, with cell killing ranging from $20 \%-35 \%$ at voltages ranging from 200-240 V.

In preliminary trials, two electroporation media were used with little success. Poor transfection efficiency was achieved with D10 complete culture medium alone (DMEM supplemented with $10 \%$ fetal bovine serum; $10 \mu \mathrm{g}$ $\mathrm{pEGFP} / 400 \mu \mathrm{L}$ complete medium), as well as $360 \mu \mathrm{L}$ D10 plus $40 \mu \mathrm{L} 150$ $\mathrm{mM}$ sucrose $(10 \mu \mathrm{g}$ pEGFP/400 $\mu \mathrm{L}$ medium). In fact, these media tended to electrically overload the RF module when pulses higher than $200 \mathrm{~V}$ were used. Consistent results were achieved with phosphate-buffered sucrose medium, pH 7.5 (as described previously) across a large range of voltage settings (190-260 V) and burst durations (1-15 ms) without the problem of electrically overloading the device. Optimal results were obtained at settings of $230 \mathrm{~V}$ and $4 \mathrm{~ms}$ burst duration using approximately 5 million 293 cells and $10 \mu \mathrm{g}$ pEGFP suspended in $400 \mu \mathrm{L}$ phosphatebuffered sucrose medium. High per- centages of transfected cells, generally greater than $50 \%$ efficiency (and even up to $73 \%$ ) were also obtained at settings of $210 \mathrm{~V} / 4 \mathrm{~ms}$ and $220 \mathrm{~V} / 4 \mathrm{~ms}$ with this electroporation buffer. Additionally, it should be stressed that this resulted in much greater cell viability compared with standard electroporation.

In conclusion, this protocol for RF electroporation of 293 cells represents an improved method for transfecting 293 cells with plasmid DNA. It can potentially be applied to a variety of other cells types with some adjustment of electroporation parameters. A greater than $50 \%$ transfection efficiency was seen in the B cell line, BJAB, on multiple occassions using similar parameters ( $210 \mathrm{~V} / 4-5 \mathrm{~ms}$ or $230 \mathrm{~V} / 4 \mathrm{~ms}$ ) to those used with 293 cells (data not shown). The 293 cell line is commonly used in laboratories where transient transfections are used routinely. Thus, radio frequency electroporation provides a simple and familiar method for increasing transfection efficiency with wide applicability.

\section{REFERENCES}

1.Barre, F., L.M. Mir, Y. Lecluse and A. Harel-Bellan. 1998. Highly efficient oligonucleotide transfer into intact yeast cells using square-wave pulse electroporation. BioTechniques 25:294-296.

2.Becker, D.M. and L. Guarente. 1991. Highefficiency transformation of yeast by electroporation. Methods Enzymol. 194:182-187.

3.Chang, D.C. 1989. Cell poration and cell fusion using an oscillating electric field. Biophys. J. 56:641-652.

4.Chang, D.C., P-Q. Gao and B. Maxwell. 1992. High efficiency gene transfection using a radio frequency electric field. Biochim. Biophys. Acta 1992:153-360.

5.Chang, D.C., J.R. Hunt, Q. Zheng and P-Q. Gao. 1992. Electroporation and electrofusion using a pulsed radio-frequency electric field, p. 303-326. In Guide to Electroporation and Electrofusion. Academic Press, New York.

6.Chang, D.C. and T.S. Reese. 1990. Changes in membrane structure induced by electroporation as revealed by rapid-freezing electron microscopy. Biophys. J. 58:1-12.

7.Chen, C. and H. Okayama. 1987. High efficiency transformation of mammalian cells by plasmid DNA. Mol. Cell. Biol. 7:2745-2752.

8.Cubitt, A.B., R. Heim, S.R. Adams, A.E. Boyd, L.A. Gross and R.Y. Tsien. 1995. Understanding, improving, and using green fluorescent proteins. Trends Biochem. Sci. 20:448-455.

9.Kingston, R.E. 1997. Introduction of DNA into mammalian cells, p. 9.1.1-9.1.4. In F.M. Ausubel, R. Brent, R.E. Kingston, D.D. Moore, J.G. Seidman, J.A. Smith and K. Struhl (Eds.), Current Protocols in Molecular Biology. John Wiley \& Sons, New York.

10.Meldrum, R.A., M. Bowl, S.B. Ong and S. Richardson. 1999. Optimisation of electroporation for biochemical experiments in live cells. Biochem. Biophys. Res. Commun. 256:235-239.

11.Orlowski, S. and L.M. Mir. 1993. Cell electropermeabilization: a new tool for biochemical and pharmacological studies. Biochim. Biophys. Acta 1154:51-63.

12.Toneguzzo, F., A. Hayday and A. Keating. 1986. Electric field-mediated transfer: transient and stable gene expression in human mouse lymphoid cells. Mol. Cell. Biol. 6:703706.

We thank Dr. Vojo Deretic for use of his microscope and digital imaging system and Cliff Boucher for technical assistance. The 293 cell line was a gift from Elliott Kieff. E.S.R. is a Scholar of the Leukemia Society of America. M.A.C. is supported by funds through the Medical Scientist Training Program from the National Institute of General Medical Sciences (NIH 5 T32 GM07863). P.B.Z. is supported by funds from the Undergraduate Research Opportunities Program at the University of Michigan. This work is supported by grants from the Leukemia Society of America, the American Heart Association AHA9650467N, the National Cancer Institute (CA072150-01) and an internal grant from the University of Michigan Comprehensive Cancer Center to E.S.R. Address correspondence to Dr. Erle S. Robertson, Department of Microbiology and Immunology and Cellular and Molecular Biology Graduate Program, 1150 West Medical Center Drive, University of Michigan Medical School, Ann Arbor, MI 481090620, USA.Internet: esrobert@umich.edu

Received 14 June 1999; accepted 29 November 1999.

\section{Philip B. Zald, Murray A. Cotter II and Erle S. Robertson University of Michigan Ann Arbor, MI, USA}

